\title{
Butyltins Contamination in Surface Water in Three Gorges Reservoir Region, China
}

Gao Jun-min, Zhang Ke, Zhou Bin, Guo Jin-song Key Laboratory of the Three Gorges Reservoir Region's EcoEnvironment, Ministry of Education Chongqing University, Chongqing, China

gao-junmin@cqu.edu.cn

\begin{abstract}
In order to know the occurrence of butyltins in water environment in Three Gorges Reservoir Region (TGRR), China, surface water samples from Chongqing to Yichang in TGRR were collected in March 2012. All water samples were extracted by solid phase micro-extraction (SPME) and measured by gas chromatograph (GC) with mass spectrum (MS). Results showed that both the mainstream and tributaries of Yangtze River in TGRR were polluted with butyltins, and the concentrations of butyltins did not exhibit any specific trend of variation in surface water along the Yangtze River. Most of butyltins were MBT which was found in 21 of 28 sampling stations, and concentrations varied from ND to $38.90 \mathrm{ng} \mathrm{Sn} / \mathrm{L}$. TBT was the next most commonly found in 9 of 28 stations with the highest level of $393.35 \mathrm{ng} \mathrm{Sn/L}$. DBT had the lowest detection rate and was detected only in 1 of 28 stations with the level of 23.09 $\mathrm{ng} \mathrm{Sn/L}$ in Tongguanyi. Butyltin degradation index (BDI) in the surface water in TGRR suggested that fresh TBT inputs or may also be attributed to very slow degradation in this region. Our study indicated that the main source of TBT contamination in TGRR may attribute to shipping activities and that particular attention should be paid to the issue of butyltins pollution in TGRR.
\end{abstract}

Keywords - Endocrine Disrupting Chemicals; Three Gorges Reservoir Region; Butyltins; Surface Water; Distribution.

\section{INTRODUCTION}

Tributyltin (TBT) compounds were widely used as a wood preservative, molluscide, insecticide, and an antifouling toxicant in boat paints [1]. However, TBT is one of endocrine disrupting chemicals (EDCs) and shows a high toxic effect to aquatic life. Even at low nanomolar aqueous concentration (1$2 \mathrm{ng} / \mathrm{L})$ TBT causes chronic and acute poisoning of the most sensitive aquatic organisms, such as algae, zooplankton, mollusks and the larval stage of some fish [2]. For example, it was reported that TBT at $2 \mathrm{ng} / \mathrm{l}$ would inhibit calcification in Crassostrea gigas [3] and induce imposex in the dogwhelk Nucella lapilluss [4]. Although TBT has been legislatively banned in antifouling paints from the late 1990s in most European and North American countries [5] due to its toxicity to aquatic life at low concentration, contamination continues in the aquatic environment, and environmental concentrations remain high enough to warrant continued concern [6-7]. In China, there are no specific legal restrictions concerning TBTcontaining antifouling paints until June, 2011. Fragmentary data about the occurrence of butyltin compounds showed that

\author{
Jin Fen \\ Key Lab of Agro-product Quality and safety, Institute of \\ Quality Standards \& Testing Technology for Agro-products, \\ Beijing, China \\ jinfenbj@163.com
}

some aquatic environment in China had been polluted by butyltin compounds [8-11].

The Yangtze River is the third largest river in the world and the Three Gorges Dam (TGD) impounds the Yangtze River for the world's largest project for hydroelectric power generation in terms of installed capacity. Surface water in Yangtze River is commonly used as the raw water source for public water supply in the region besides being considered for the provision of fresh water to the dryer northern part of China, as part of the south-north water diversion project. However, water quality in the Yangtze river and its tributaries in Three Gorges Reservoir Region is of major concern, because growing anthropogenic pollutants currently enter the water environment in this region from household sewage, industrial discharge, waste water treatment plant outflows, garbage dumping, and agricultural runoff and productive and protected groundwater resources are rare in the catchment area of the TGR ${ }^{[12-13]}$. Existing data showed Yangtze River in Three Gorges Reservoir region was polluted by organotins [10-11].

In this paper, the occurrence of TBT and its metabolic product of MBT and DBT in water environment in TGRR from Jiangjin to TGD were investigated by solid-phase microextraction (SPME)-gaschromatography (GC)massspectrometry (MS) combined with ethylation, and the proportion distribution of different butyltins in TGRR was also described.

\section{MATERIALS AND METHODS}

\section{A. Reagents and instruments}

Monobutyltin trichloride (MBT, 97\%), dibutyltin dichloride (DBT, 97\%), and tributyltin chloride (TBT, 95\%) were purchased from ACROS ORGANICS (Geel, Belgium). Sodium tetraethylborate $\left(\mathrm{NaBEt}_{4}, 98 \%\right)$ was purchased from CNW Technologies GmbH (German). Deuterated organotins, MBT-d9, DBT-d18, and TBT-d27 were purchased from Hayashi Pure Chemicals (Tokyo, Japan). Methanol was of high performance liquid-chromatography (HPLC) grade obtained from Fisher Scientific (NJ, USA), and tetrahydrofuran was of HPLC grade obtained from DIKMA (CA, USA).

Water was obtained by a compact ultrapure water system Mili-QACADEEMIC (MILLIQ, France). Individual stock solutions of organotins were prepared in methanol. A working 
solution of mixed organotins was also prepared using methanol as solvent. This solution was diluted in methanol as required. Fresh $\mathrm{NaBEt}_{4}$ solution of $4 \%(\mathrm{w} / \mathrm{v})$ was prepared with tetrahydrofuran monthly. An acetate buffer $(\mathrm{pH}=4)$ was made from acetic acid and sodium acetate solution. All the solutions were stored at $4{ }^{\circ} \mathrm{C}$ in the dark.

An SPME holder and a fiber coated with a $100 \mu \mathrm{m}$ layer of polydimethylsiloxane were obtained from Supelco (Bellefonte, PA, USA). GC-MS analysis was performed with 7890A5975C gas chromatograph mass spectrometer (Agilent, USA) using electron impact in the selected ion monitoring (SIM) mode. A Agilent DB-5 capillary column $(30 \mathrm{~m} \times 0.25 \mathrm{~mm}$ i.d. with a $0.025-\mu \mathrm{m}$ film thickness) was used for organotins analysis.

\section{B. Sampling and analysis}

The studied area is located in TGRR. In the study area, total of 28 sites from Jiangjin to TGD were selected (Fig. 1). Excepting stations 4, 7, 8, 16, 17, 21, 22, 25, 26 are in the tributaries of Yangtze River, other stations were located in the mainstream of Yangtze River. Surface water samples were manually collected in the middle of the river from just beneath the surface in March, 2010. Geographical coordinates were determined with a mobile GPS at each sampling station. All surface water samples were collected at two replicates from every site and were acidified with $\mathrm{HCl}$ solution $(6 \mathrm{~N})$ to $\mathrm{pH}=2$ on-site. Then water samples were brought to laboratory and stored at $4^{\circ} \mathrm{C}$.

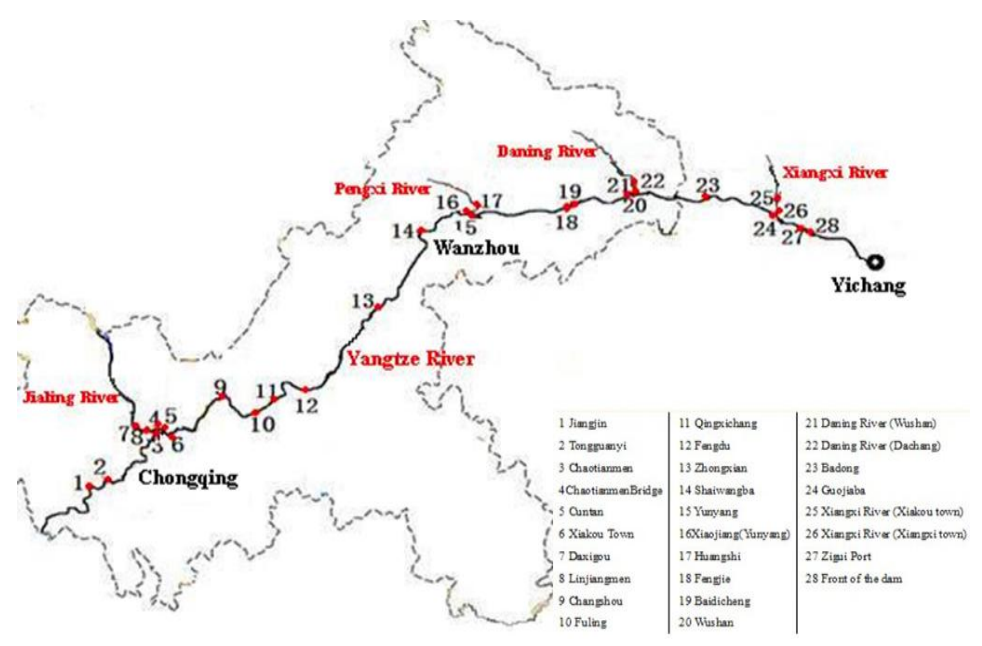

Fig. 1. Sampling points in TGRR

Analysis and quantification of organotins in water samples was improved based on the methods reported in previous studies [10-11]. In brief, a $100 \mu \mathrm{L}$ mixed solution containing 40 ppb of each isotope compound was added into $20 \mathrm{~mL}$ of water samples in $40 \mathrm{~mL}$ amber glass vials. After adding $2 \mathrm{~mL}$ of

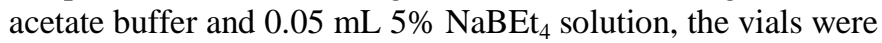
immediately sealed with PTFE-lined silicon septa, and the contents were stirred on a magnetic stirrer. The SPME fiber was then exposed to the headspace over the vigorously stirred solution at $80^{\circ} \mathrm{C}$. After $20 \mathrm{~min}$, the fiber was withdrawn into the needle of the holder and was placed in the GC injector for 2-3 min. The temperature programs used for the GC column were $60^{\circ} \mathrm{C}$ for $1 \mathrm{~min}, 10^{\circ} \mathrm{C} / \mathrm{min}$ to $180^{\circ} \mathrm{C}, 5^{\circ} \mathrm{C} / \mathrm{min}$ to $220^{\circ} \mathrm{C}$, then $30^{\circ} \mathrm{C} / \mathrm{min}$ to $280^{\circ} \mathrm{C}(2 \mathrm{~min})$. The injector temperature was maintained at $270{ }^{\circ} \mathrm{C}$, and the detector source temperature was kept at $300^{\circ} \mathrm{C}$. Fragment ions that were selected to quantitative analysis in selected ion monitoring mode (SIM) are listed in Table 1.

TABLE I. IONS MONITORED IN SIM MODE

\begin{tabular}{|c|c|c|}
\hline time window $(\mathbf{m i n})$ & Analyte & Ion monitored \\
\hline $7.5-8.11$ & MBT-d9 & $180,242,244$ \\
\hline $8.11-10.00$ & MBT & $149,179,233,235$ \\
\hline $10.00-10.27$ & DBT-d18 & $217,279,281$ \\
\hline $10.27-11.00$ & DBT & $149,179,207,263$ \\
\hline $11.80-12.18$ & TBT-d27 & $153,190,217$ \\
\hline $12.18-16.30$ & TBT & $149,177,207,263$ \\
\hline
\end{tabular}

\section{RESULTS AND DISCUSSION}

The butyltin compounds concentrations in unfiltered surface water samples from 28 stations in TGRR are shown in Table 2, and the proportion distribution of different butyltins in water samples are shown in Fig.2. Butyltin compounds were detected in all stations except station 3, 4, and 5, which suggests that both the mainstream and tributaries of Yangtze River are polluted with butyltins. The range of total butyltins in tributaries of Yangtze River were ND 38.90 ng Sn/L, but the range of total butyltins in mainstream were ND 393.73 ng $\mathrm{Sn} / \mathrm{L}$ due to high concentration of TBT in station 27 (Zigui Port). Most of butyltins were MBT which was found in 21 of 28 sampling stations, and concentrations varied from ND to $38.90 \mathrm{ng} \mathrm{Sn} / \mathrm{L}$. TBT was the next most commonly found in 9 of 28 stations with the highest level of $393.35 \mathrm{ng} \mathrm{Sn/L.} \mathrm{DBT}$ had the lowest detection rates and was detected with the level of $23.09 \mathrm{ng} \mathrm{Sn/L} \mathrm{in} \mathrm{Tongguanyi} \mathrm{(station} \mathrm{2).}$

The quantitative importance of TBT degradation can be evaluated following a TBT degradation index. Butyltin degradation index (BDI) (Table 2) is calculated as

$$
\mathrm{BDI}=\left[\frac{(\mathrm{DBT}+\mathrm{MBT})}{\mathrm{TBT}}\right]
$$

BDI $<1$ indicates recent input of TBT [14]. In the TGRR, the BDI calculated ranged from $<0.01$ to 2.21 in the surface water (Table 2). Five of the surface water samples from stations 9, 16, 19, 27, and 28 respectively, showed $\mathrm{BDI}<1$ especially stations 19 and 27 . Moreover, high concentration of TBT was detected in stations 10, 25, 26, but no DBT and MBT were detected in those stations. Above results suggested that fresh TBT inputs or may also be attributed to very slow degradation in those stations, and 'hot spots' of TBT occurred from time to time. These areas include ports and industrial zones, suggesting release of TBT from large shipping vessels and through industrial effluents released into the water environment. Additionally, MBT and/or DBT in surface water samples were detected in some stations but where TBT was 
not detectred, which implying that MBT and DBT may enter aqueous systems by leaching from poly(viny1 chloride) and chlorinated poly(viny1 chloride) plastics[15]. However, in the absence of such inputs, the presence of MBT and DBT is likely due to dealkylation of the TBT species, particularly in areas where antifouling paints containing TBT as a biocide are used routinely.

TABLE II. LEVELS OF ORGANOTINS IN TGRR

\begin{tabular}{|c|c|c|c|c|c|c|c|c|}
\hline \multirow[t]{2}{*}{ No. } & \multirow[t]{2}{*}{ Sampling sites } & \multicolumn{2}{|c|}{$\begin{array}{l}\text { Position coordinate } \\
\end{array}$} & \multicolumn{4}{|c|}{ Concentration (ng Sn/l) } & \multirow[t]{2}{*}{ BDI } \\
\hline & & North latitude & East longitude & MBT & DBT & TBT & $\sum$ butyltins & \\
\hline 1 & Jiangjin & $106^{\circ} 23.166^{\prime}$ & $29^{\circ} 17.662^{\prime}$ & 11.20 & $\mathrm{ND}^{*}$ & ND & 11.20 & - \\
\hline 2 & Tongguanyi & $106^{\circ} 14.729^{\prime}$ & $27^{\circ} 17.498^{\prime}$ & ND & 23.09 & ND & 23.09 & - \\
\hline 3 & Chaotianmen & $106^{\circ} 35.132^{\prime}$ & $29^{\circ} 34.161^{\prime}$ & ND & ND & ND & ND & - \\
\hline 4 & Chaotianmen.Bridge & $106^{\circ} 34.768^{\prime}$ & $29^{\circ} 35.107^{\prime}$ & ND & $\mathrm{ND}$ & ND & ND & - \\
\hline 5 & Cuntan & $106^{\circ} 35.815^{\prime}$ & $29^{\circ} 37.239^{\prime}$ & ND & $\mathrm{ND}$ & $\mathrm{ND}$ & $\mathrm{ND}$ & - \\
\hline 6 & Xiakou Town & $106^{\circ} 40.064^{\prime}$ & $29^{\circ} 33.985^{\prime}$ & 23.77 & $\mathrm{ND}$ & $\mathrm{ND}$ & 23.77 & - \\
\hline 7 & Daxigou & $106^{\circ} 33.220^{\prime}$ & $29^{\circ} 34.181^{\prime}$ & 13.47 & $\mathrm{ND}$ & ND & 13.47 & - \\
\hline 8 & Linjiangmen & $106^{\circ} 34.899^{\prime}$ & $29^{\circ} 34.137^{\prime}$ & 12.38 & ND & ND & 12.38 & - \\
\hline 9 & Changshou & $107^{\circ} 03.544^{\prime}$ & $29^{\circ} 49.277^{\prime}$ & 0.21 & ND & 13.88 & 14.08 & 0.01 \\
\hline 10 & Fuling & $107^{\circ} 23.654^{\prime}$ & $29^{\circ} 42.858^{\prime}$ & ND & ND & 9.11 & 9.11 & - \\
\hline 11 & Qingxichang & $107^{\circ} 27.345^{\prime}$ & $29^{\circ} 45.857^{\prime}$ & 11.01 & ND & ND & 11.01 & - \\
\hline 12 & Fengdu & $107^{\circ} 43.087^{\prime}$ & $29^{\circ} 52.206^{\prime}$ & 8.61 & $\mathrm{ND}$ & ND & 8.61 & - \\
\hline 13 & Zhongxian & $108^{\circ} 02.731^{\prime}$ & $30^{\circ} 18.209^{\prime}$ & 9.15 & ND & ND & 9.15 & - \\
\hline 14 & Shaiwangba & $108^{\circ} 27.024^{\prime}$ & $30^{\circ} 40.661^{\prime}$ & 4.57 & ND & ND & 4.57 & - \\
\hline 15 & Yunyang & $108^{\circ} 40.804^{\prime}$ & $30^{\circ} 56.378^{\prime}$ & 7.16 & ND & ND & 7.16 & - \\
\hline 16 & Xiaojiang(Yunyang) & $108^{\circ} 40.722^{\prime}$ & $30^{\circ} 56.607^{\prime}$ & 2.64 & $\mathrm{ND}$ & 3.45 & 6.09 & 0.77 \\
\hline 17 & Huangshi & $108^{\circ} 42.976^{\prime}$ & $30^{\circ} 599.50^{\prime}$ & 22.95 & ND & ND & 22.95 & - \\
\hline 18 & Fengjie & $109^{\circ} 28.40^{\prime}$ & $31^{\circ} 01.223^{\prime}$ & 2.59 & $\mathrm{ND}$ & ND & 2.59 & - \\
\hline 19 & Baidicheng & $109^{\circ} 33.326^{\prime}$ & $31^{\circ} 02.656^{\prime}$ & 0.38 & $\mathrm{ND}$ & 72.67 & 73.05 & 0.01 \\
\hline 20 & Wushan & $109^{\circ} 51.697$ & $31^{\circ} 04.349^{\prime}$ & 4.82 & $\mathrm{ND}$ & ND & 4.82 & - \\
\hline 21 & Daning River (Wushan) & $109^{\circ} 52.697^{\prime}$ & $31^{\circ} 04.349^{\prime}$ & 38.90 & ND & ND & 38.90 & - \\
\hline 22 & Daning River (Dachang) & $109^{\circ} 53.704^{\prime}$ & $31^{\circ} 04.349^{\prime}$ & 38.08 & ND & ND & 38.08 & - \\
\hline 23 & Badong & $109^{\circ} 49.034^{\prime}$ & $31^{\circ} 15.133^{\prime}$ & 3.01 & $\mathrm{ND}$ & 1.36 & 4.37 & 2.21 \\
\hline 24 & Guojiaba & $110^{\circ} 45.095^{\prime}$ & $30^{\circ} 57.444^{\prime}$ & 2.72 & ND & ND & 2.72 & - \\
\hline 25 & Xiangxi River (Xiakou town) & $110^{\circ} 47.055^{\prime}$ & $31^{\circ} 07.298^{\prime}$ & ND & $\mathrm{ND}$ & 15.92 & 15.92 & - \\
\hline 26 & Xiangxi River (Xiangxi town) & $110^{\circ} 45.630^{\prime}$ & $30^{\circ} 58.005^{\prime}$ & ND & $\mathrm{ND}$ & 22.63 & 22.63 & - \\
\hline 27 & Zigui Port & $110^{\circ} 15.518^{\prime}$ & $30^{\circ} 51.020^{\prime}$ & 0.38 & $\mathrm{ND}$ & 393.35 & 393.73 & $<0.01$ \\
\hline 28 & Front of the dam & $110^{\circ} 59.255^{\prime}$ & $30^{\circ} 49.828^{\prime}$ & 3.12 & ND & 27.66 & 30.78 & 0.11 \\
\hline
\end{tabular}

ND* indicated that the concentration was below the detection limit.

As the concentrations of butyltins in surface water are greatly dependent on many influencing factors, such as the distribution of pollution sources, the release of pollutants, the hydrodynamic conditions, and the temperature of water body and so on, the butyltins do not exhibit any specific trend of variation in surface water along the Yangtze River. Both the mainstream and tributaries of Yangtze River especially mainstream are important Shipping lanes in TGRR, and there are many shipping activities in this region especially in some ports. Therefore, the main source of TBT contamination in TGRR may attribute to shipping activities in this region. For example, Zigui Port is a big port with many Cargo ships and cruise ships and where the water keeps moving slowly, so the highest concentration of TBT was detected in Zigui Port. However, although Chaotianmen is a dock with some ships too, no butylitns were detected in Chaotianmen in this study. Chaotianmen is the confluence of Yangtze River and Jialing Rivers and where the water moves quickly. No butylitns were detected in Chaotianmen which can be ascribed to the fast-flowing water which diluted pollutants in water body.

Except possibly where a locally important species is very sensitive, freshwater aquatic organisms and their uses should not be affected unacceptably if the four-day average concentration of tributyltin does not exceed $0.063 \mathrm{ug} / \mathrm{l}$ more than once every three years on the average and if the one-hour average concentration does not exceed $0.46 \mathrm{ug} / \mathrm{l}$ more than once every three years on the average [16]. In 9 stations where

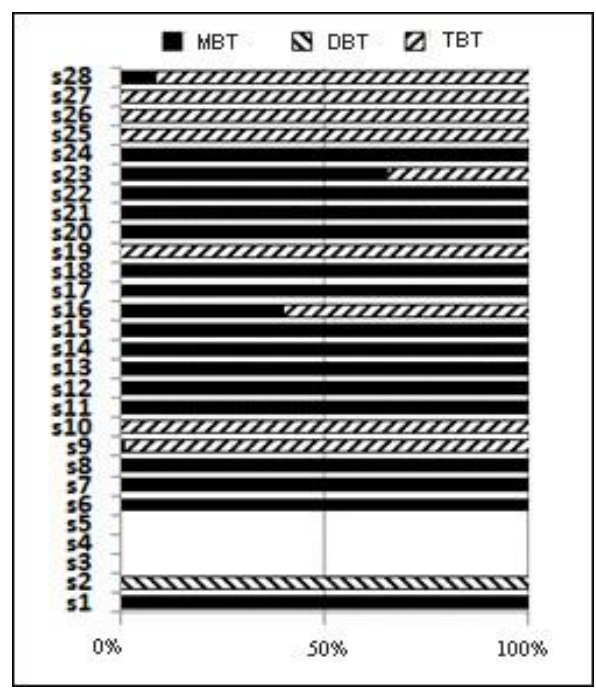

Fig. 2. The proportion distribution of butyltins in TGRR 
TBT were detected, TBT concentration in stations 19, 27, and 28 were higher than $0.063 \mathrm{ug} \mathrm{TBT} / \mathrm{L}$ (amount to $24.61 \mathrm{ng}$ $\mathrm{Sn} / \mathrm{L}$ ) and station 27 was high than $0.46 \mathrm{ug} / \mathrm{l}$ (amount to $179.71 \mathrm{ng} \mathrm{Sn} / \mathrm{L}$ ), which suggesting probable toxic effect for freshwater aquatic organisms and their uses in these stations. Moreover, due to surface water is commonly used as the raw water source for public water supply in TGRR besides being considered for the provision of fresh water to the dryer northern part of China, and conventional treatment processes can't remove organotins completely[17], particular attention should be paid to the issue of butyltins pollution in TGRR.

\section{ACKNOWLEDGMENTS}

This study was supported by the National Natural Science Foundation of China [21107147] and Fundamental Research Funds for the Central Universities of China [CDJZR 12210016].

\section{REFERENCES}

[1] P. F. Seligman, A. o. Valklrs, and R. F.Lee, "Degradation of Tributyltin in San Diego Bay, California, Waters," Environ. Sci. Technol, 1986, 20:1229-1235

[2] M. Hoch, "Organotin compounds in the environment-an overview," Applied geochemistry, 2001, 16:719 743

[3] D. Chagot, C. Alzieu, J. Sanjuan, and H. Grizel, "Sublethal and histopathological effects of trace levels of tributyltin fluoride on adult oysters Crassostrea gigas," Aquat Liv Resour 1990,3:121130

[4] M. J. Waldock, J. E. Thain, and M. E. Waite, "The distribution and potential toxic effects of TBT in UK estuaries during 1986," Appl Organomet Chem, 1987, 1:287-301

[5] Y. K. Chau, R. G. Maguire, M. Brown, F. Yang, and S. P. Batchelor, "Occurrence of organotin compounds in the Canadian aquatic environment five years after the regulation of antifouling uses of tributyltin," Wat Qual Res J Canada, 1997, 32:453-521

[6] P. Rantakokko, A. Hallikainen, R. Airaksinen, P. J. Vuorinen, A. Lappalainen, J. Mannio, and et al. "Concentrations of organotin compounds in various fish species in the Finnish lake waters and Finnish coast of the Baltic Sea," Science of the Total Environment, 2010 (408): 2474-2481

[7] A. D. Nikolaou, G. M. Gatidou, S. K. Golfinopoulos, N. Thomaidis, and T. D. Lekkas, "A one-year survey of organotin compounds in the reservoirs supplying the drinking water treatment plants of Athens, Greece" Desalination, 2007 (210) 24-30

[8] G. B. Jiang, Q. F. Zhou, J. Y. Liu, and D. J. Wu, "Occurrence of butyltin compounds in the waters of selected lakes, rivers and coastal environments from China," Environ Pollut, 2001,115:8187

[9] J. M. Gao, J. Y. Hu, Y. Wan, W. An, L. H. An, and Z. G. Zheng. "Butyltin compounds distribution in the coastal waters of Bohai bay, People's Republic of China" Bulletin of Environmental Contamination and Toxicology, 2004, 72(5): 945-953

[10] J. M. Gao, J. Y. Hu, H. J. Zhen, M. Yang, and B. Z. Li, "Organotin compounds in the Three Gorges Reservoir Region of the Yangtze River," Bulletin of Environmental Contamination and Toxicology, 2006,76(1):155-162
[11] J. M. Gao, Y. Zhang, J. S. Guo, F. Jin, and K. Zhang. "Occurrence of organotins in the Yangtze and Jialing Rivers in the urban section of Chongqing, China," Environmental Monitoring and Assessment, 2013,185(5): 3831-3837

[12] X. Ma, Y. Li, M. Zhang, F. Zheng, S. Du, "Assessment and analysis of non-point source nitrogen and phosphorus loads in the Three Gorges Reservoir Area of Hubei Province, China," Sci Total Environ,2011,( 412-413):154-161

[13] X. Chang, M. T. Meyer, X. Liu, Q. Zhao, H. Chen, J. A, Chen, and et al. "Determination of antibiotics in sewage from hospitals, nursery and slaughter house, wastewater treatment plant and source water in Chongqing region of Three Gorge Reservoir in China," Environ Pollut, 2010,158 (5):1444-1450

[14] A. Garg, R. Antoon-Martín, E. Garc1'a-Luque, I. Riba, T. A. DelValls, "Distribution of butyltins (TBT, DBT, MBT) in sediments of Gulf of Ca'diz (Spain) and its bioaccumulation in the clam Ruditapes philippinarum," Ecotoxicology, 2009,18:1029-1035

[15] E. A. Boettner, G. L. Ball, Z. Hollingsworth, R. Aquino, Organic and Organotin Compounds Leached from PVC and CPVC Pipe; EPA Health and Effects Research Laboratory: Cincinnati, OH, 1982; EPA-600-SI-81-062

[16] Ambient aquatic life water quality criteria for Tributyltin(TBT)draft, United States EPA-822-B-02-001,2002

[17] J. M. Gao, J. Y. Hu, H. J. Zhen, X. H. Jin, B. Z. Li, "Occurrence and Fate of Organotins in a Waterworks in North China," Bulletin of Environmental Contamination and Toxicology, 2009,83:295-299 